\title{
Introduction
}

This book explores the imaginary possibilities of freedom in the aftermath of the critique of human rights. Addressing this issue in relation to gender and alterity, I specifically focus on how, in light of such critique, freedom is to be envisaged once the emancipatory claims of human rights have proven disingenuous, false or simply unrealizable. In the global context, freedom remains defined as a liberal, external pursuit, involving the accumulation of further rights by a rational, finite and individual subject. The critical legal project, including postcolonial and feminist interventions, has successfully dismantled the façade of this claim, exposing the regulatory and governance structures of human rights. The central endeavour of this book is to consciously explore the imaginary possibilities that have emerged in the aftermath of critique by centring and examining articulations of freedom available in non-liberal, alternative epistemologies. I address alternative registers that present radical insights on freedom as based on discrete understandings of the subject which are distinct from/remain beyond the reach of liberal individualism, and posit notions of self-scrutiny, reflection, discernment and the turn inwards as central features.

The focus on non-liberal (as opposed to illiberal) articulations of freedom pushes against the liberal positioning of human rights as indispensable central instruments in struggles for freedom, and further questions their capacity to realize this goal. The discussion not only exposes the parochial, provincialized identity of human rights as liberal, overwhelmingly Western and Eurocentric, but also displays the destructive capacities nestled in the liberal claim to ideological supremacy - one that ultimately seeks to retain its dominance over all others through its coercive formulations of how to be, and be free, in the world. The notion that divergent understandings of freedom have always existed outside of the liberal and neoliberal imaginaries and related market terms is either barely considered by those who shape, support and implement the rights regime, or considered inherently alien and therefore irrelevant to the recursive ideological currents within the fishbowl. This book sets the stage for the argument that freedom should be actively delinked from the human rights project as formulated and imposed by the liberal 
imaginary, and should instead be explored within a range of dynamic and existing alternative philosophical spaces. By exploring whether, and how, non-liberal vocabularies of freedom can address and alleviate the current disillusionment with human rights' capacity to deliver on their emancipatory promise, the book marks a conscious and productive shift in the direction of visualizing the concept of freedom from outside the liberal fishbowl, and exploring considerations of freedom that have always existed beyond the fishbowl.

My analysis is not framed within an either/or binary - that is, between support for the human rights project and a specific intervention (which can have disastrous and unintended consequences), and a refusal to intervene that closes its eyes to the repression and violence experienced by sexual and religious minorities and women (for the most part, it is generally alleged, in rogue, non-Western states). Instead, my starting premise accepts the idea of human rights as a project that is already affected by - and overtly and covertly implicated in - structures of power, laying bare the fallacy of human rights as linked to an external, optimistic pursuit of freedom. Thus, this book does not offer a comprehensive account of critical approaches to human rights, nor is it an encyclopaedic presentation of women's human rights and LGBT advocacy. Instead, in the initial chapters, I consider significant moments in gender and sexual rights advocacy and illustrate the work of human rights within these interventions. I set out the concerns around freedom that emerge from this line of inquiry, including the discursive and normative effects produced through these struggles for legibility and entitlement. Tracing the work of human rights within these specific advocacy pursuits, I demonstrate how even the minimalist claims of human rights advocates - that rights can alleviate human suffering and do not have wider effects - are invariably advancing maximalist projects, such as the need for thriving markets or the embedding of a particular notion of the female subject as unveiled, sexualized and autonomous. I offer insights into the core motives of rights strategies in relation to gender and alterity that are either seldom discussed or made visible, or not seen as politically relevant. The trail of disorder, chaos and, at times, unanticipated but irrefutably harmful outcomes produced in and through human rights advocacy, as delineated in the different chapters of this book, underscores the urgent need to identify new ways of pursuing freedom. I pose a direct challenge to the idea that rights accumulation by the individual can lead to freedom, thus shifting away both from the liberal conception of freedom as an exclusively external, progressive pursuit and from the assumption within human rights discourse that liberal understandings of freedom are the only available and valid ones. 
My effort is partly to centre the idea that rights are techniques of governance which discipline and regulate the subject of human rights, and where practices of self-discipline and self-governance become normalized and experienced as freedom. Simultaneously, I question why the burgeoning critical scholarship on human rights more generally has not necessarily been productive or creative enough in scrutinizing this self-referential schema of entitlement. On the one hand, political interventions are regarded with paranoia, and all those features of human rights that hold out the possibility of hope and transformation are treated with suspicion. On the other, the scholarship has tended to offer reformulations and, somewhat awkwardly (and unsuccessfully), has sought to reinstall the project of human rights through proposals of pragmatic renewal and reinvestment. Rather than theorizing strategies of empowerment that take us further in the direction of freedom, these proposals speak more to anxiety and fear about 'letting go' of a project that has been so cherished over the past half-century. The theoretical turn back to human rights is in fact reflective of the anxiety that accretes around the notion of the epistemic void that, from the liberal perspective, would presumably result from any subversion or deconstruction of the existent rights framework. In this sense, as Golder asserts, despite delivering a devastating critique of human rights as 'a particular form of Western political liberalism that gets exported globally with great violence ... critical commentators on human rights nevertheless make a curious return to human rights'. ${ }^{1}$

While I acknowledge the intrinsic, though qualified, benevolence associated with proposals that offer a reformulation and reinvestment in human rights, such reformulations cannot lead to freedom. The commitment to reimagining and reformulating human rights and its futurity is largely informed not only by a fear that the critique will send us into epistemic free fall, but also by the erroneous assumptions that there are no workable or sustainable alternatives outside of a liberal formulation or reformulation, and that any ventures beyond the liberal fishbowl are nihilistic and defeatist. Yet the persistent faith in human rights and allegiance to paradigms of freedom formulated and upheld within the liberal fishbowl not only remains embedded in a 'cruel optimism', but also represents a nihilistic move that can take us no further in the direction of freedom. The end result is a continuing subscription to the paradigms of freedom and happiness formulated and upheld within the liberal fishbowl, despite repeated evidence of the limitations of the human rights project and its ideological and material deployments, which have undeniably often produced ferocious outcomes and immense suffering. 
Thus, contemporary critique finds itself at an impasse, and the core questions remain unaddressed: What happens when the faith in human rights as a liberal freedom project is so substantively eroded? Where does that leave us? If human rights cannot give us what we want - namely, freedom - then what can? In the final three chapters of this book, I identify new ways of pursuing freedom that involve a turn inwards and necessarily require the self-transformation of the subject. My argument draws partly on the radical thinking of critical Western scholars such as Michel Foucault and Eve Sedgwick. Foucault's theoretical engagement with political spirituality presented in relation to the early phases of the Iranian revolution, and his articulation of the self as distinct from the liberal subject, marks a profound intervention on the idea of freedom. Similarly, Sedgwick's inquiry into Mahayana Buddhist epistemology offers an alternative model of meaningful freedom, which partly emerges from her prescient insight that critique of the dominant normative order and deconstruction inevitably leads to non-dualism. I also draw on non-liberal philosophical and agnostic spiritual traditions, such as the ecstatic registers of Persian Sufism, where freedom is expressed in intensely affective and passionate release. Towards the end of this book, I present a close reading of the non-liberal, subcontinental episteme of non-dualism - Advaita, 'not two' - to demonstrate how an alternative register is not adversarial or irrelevant to human rights, even though its inscription of selfhood and of the processes of being and becoming may seem incommensurable with the parameters of subjectivity as enunciated and affirmed within the liberal project. In each instance, what becomes evident is that meaningful freedom is possible primarily through selftransformation and self-reflection.

The questioning of human rights as a freedom project and the turn towards non-liberal pursuits does not imply support for the rhetoric of cultural relativists, or ideologues of various persuasions, who foment collective practices that are inhuman and antihuman and who might embrace the critique as a justification for refuting the human rights project and embracing cultural orthodoxies. In fact, my argument seeks to occupy the semantic and political 'non-liberal' space that has all too often and easily been ceded to reactionary influences and orthodoxies by progressive, feminist, and leftist forces out of fear that it may mark them as 'religious' or unsecular. Nor does the proposed shift require abandoning human rights. Rather, it requires comprehending the work that human rights do primarily as regulatory and governance mechanisms. This process involves taking a step back and directing one's gaze behind the liberal paradigm of freedom and the notions of happiness and the 'good life' that arise from the fishbowl, and which comprise part of the 
ostensibly progressive and benevolent arsenal of human rights. Such critical objectivity is vital to any understanding of the full array, as well as the specific architecture, of the practices, assumptions and dogmas that shape the contemporary rights project.

Thus, the argument put forth in this book is not about negating the human rights project, even if that were desirable or possible in these exceedingly violent times. Rather, my analysis is underpinned by a call for a more mindful and diligent approach. It is a proposal to consciously take a step back and objectively evaluate what has been gained through the ethics and mechanics of the current model of human rights advocacy, and what has been - perhaps irretrievably - lost. Today, instead of promoting an arrogant triumphalism or succumbing to frustrated hopelessness, human rights advocacy requires substantive investment in practices of thoughtful self-scrutiny; scrutiny of one's 'Other/s', whomever or whatever they might be; and an inclusive dialogue not just within the rights establishment but also with those on whose behalf rights interventions are undertaken. The politics of my critical project resides in the process of seeking; that is, the foregrounding of a modality wherein our engagement with the human rights project and its proven limits provokes our reflective rather than our reflexive responses. Only such tough, granular, committed practices of introspection will enable us to pause and take heed of what needs our urgent attention.

\section{HUMAN RIGHTS AND FREEDOM}

Human rights advocacy is based on a fundamental belief that freedom rests in the accumulation of rights, and that these in turn are always both progressive and transformative. This belief draws on the dominant liberal idea that human beings are self-directing individuals capable of pursuing the goals that they have set for themselves, and of ensuring the existence of the conditions necessary to enable them to pursue their chosen end goals free from other people's will or the constraint of another's will. This understanding also involves adhering to the fundamental principle of liberalism - namely, that any exercise of freedom is to be respected only to the extent that it does not violate the equal freedom of the other. In classical liberal terms, this idea of freedom encompasses economic features that include ownership in the form of one's labour and material possessions, as well as private property. It involves a pursuit of the 'good life' - a particular existential modality arising from a particular selfconcept that, in terms of the liberal paradigm, is essential to the wellbeing and happiness of the individual. 
Human rights have become the essential mechanism for communicating this liberal understanding of freedom, specifically 'equal' freedom, at the international level. Faith in the inherent capacity of rights to produce lasting freedom for the individual partly rests on an assumption that we have, as a civilized world, moved forward, and that the coming together of nation states in the recognition of universal human rights is a critical part of the liberal project that is committed to individual and collective human freedom. This liberal narrative is driven by a view that history has a purpose and direction, coupled with an assumption that the world has emerged from a prolonged phase of superstitious and barbarian backwardness, and is evolving towards a universalist telos of justice and equality, based on reason, science and democratic values. The conviction that civilization has metamorphosed from the anarchic and primitive to a modern superior form has emanated from the heart of Europe; ${ }^{2}$ the liberal assertion is that modernity has mostly been achieved, except in what are still regarded as 'the outposts of the empire'. The cartography of human rights has received a major impetus in the post-Cold War era in the form of liberal internationalism, which, it is claimed, no longer faces any ideological resistance except in those parts of the globe regressing into feudal despotism and/or xenophobic violence. A veneration of the ideals of modernity and a hubris born of persistent faith in the benevolence of this justice-seeking liberal project have come to characterize human rights advocacy as practised on the ground. There is a genuine earnestness on the part of well-intentioned activists, scholars, practitioners, jurists and legislators convinced that they are incontrovertibly pursuing a progressive, even righteous, universally desired goal of freedom for the individual.

This view generates and reinforces the consensus that the liberal framework within which freedom is located is the most progressive as well as civilizationally mature project for pursuing the goal of freedom. However, in recent times this assumption has been challenged as empirically and theoretically flawed: in purely factual terms, more human rights violations have been committed in the twentieth century - ostensibly the century most focused on human rights - than at any other point in human history. ${ }^{3}$ There is a less benevolent side to human rights work that has been exposed by critical legal scholars, including feminist and postcolonial intellectuals. ${ }^{4}$ These scholars have examined - and revealed the costs of such work, including the often unanticipated damage inflicted in the name of procuring and securing freedom. This scholarship contests the idea of human rights as a liberatory project and one that will incontrovertibly secure our freedom, instead exposing it as a governance project - one that systematically regulates, disciplines and manages 
different lives and bodies. This critique produces a counter-narrative of human rights, subverting their unequivocally generous primary intent and the dominant assumption that they are a progressive, democratic and liberating force, integral to any experience of freedom. The rights rationale has also been efficiently co-opted to advance the agendas of large corporations and the military machines of powerful states. ${ }^{5}$

Contemporary critiques have increasingly identified what David Kennedy would describe as the 'dark side' of an ostensibly virtuous project, providing some insight into the interventionist conceits that human rights advocates consistently display with a disturbing lack of self-reflection. ${ }^{6}$ This book builds upon that body of critical scholarship, which has challenged the accuracy of the claim that the human rights project regarded as a manifestation of the liberal political episteme wherein the subject as a bearer of rights occupies a central position - can actually produce meaningful freedom and happiness through the continued acquisition of further rights. Locating the discussion within the context of gender and sexual rights advocacy, the first part of the book critically examines liberal conceptions of freedom and the assumption within human rights discourse that liberal understandings of freedom are the only available and valid ones. In the second part of the book, I identify new ways of pursuing lasting freedom without surrendering the terrain of human rights, although the relationship between the two projects may ultimately be incommensurable.

I draw considerably on critical legal theory to develop my critique of liberal freedom and the way that human rights attaches to the liberal enunciation. I demonstrate how the latter is in fact a technique of global governance and one in which the embrace of neoliberal markets serves as the most potent instrument through which such freedom is to be attained. In this vision, power operates to ensure that the governed themselves come to see behaving in a certain way as ethical and desirable, and as arising from their own freedom, procured and secured for them by those who govern. Furthermore, a postcolonial analysis that reconfigures dominant narratives by including the 'small voice of history'7 destabilizes the primary assumptions about freedom on which the liberal human rights endeavour is based. It addresses how contemporary inequalities have been informed by their historical past, where the colonized 'Other' was deemed 'backward' by liberal political thinkers, both in terms of culture and in their ability to consent, and hence these features justified the legal difference in treatment. Under the conditions of liberalism and empire, juridical entitlements were integrally linked to recognition of the 'Other' as variously either fully human, a lesser human or a non-human. 
Scholars differ on the 'origins' of human rights and when and how they became relevant, ${ }^{8}$ or whether they remain relevant at all, given their inability to reduce harm and violence in an increasingly violent world. ${ }^{9}$ My critical focus in this book concerns how the liberal worldview, which includes human rights - whether in the older guise of a civilizing mission or in its contemporary manifestation, where it is aligned with the market and global capital - is today intent on permeating all modalities of human relationships. ${ }^{10}$ As a modality of liberalism, rights have without exception demonstrated an imperialistic trajectory and an understanding of freedom as a technique of governance as opposed to liberation. They have continued to be mapped and deployed along the axis of inclusion and exclusion - a discriminatory heuristic that is integral to the human rights endeavour, rather than a detour from or failure of the project. My analysis of this project brings into crisis the central pillars of liberalism present regardless of its various disputatious guises and forms - on which the human rights enterprise is based: the universal, rational subject and the idea of freedom as an external pursuit; the march forward towards a common progressive end through the systematic accumulation of rights; and the valorizing of 'public' and 'private' as two distinct, separate spheres of human activity that must never infiltrate or influence each other.

Critical approaches to human rights have been enormously significant in unmasking the normative and regulatory arrangements that constitute human rights. The early chapters in the book work with this critical tradition to examine how gender and sexual rights advocacy has invariably reinforced these arrangements, rather than brought about transformation and meaningful freedom for the concerned disenfranchised constituencies. While such engagements produce moments of disruption in normative assumptions about gender, sexuality and culture, they are illustrative of the resistive capacities of the subaltern subject, rather than productive of meaningful freedom. Critical human rights scholarship has exposed the discursive operations of human rights as irrefutably hegemonic: a governance project primarily concerned with ordering the lives of non-European peoples and creating the conditions for the exponential flourishing of the neoliberal market with the bulk of profits channelled to further enrich a privileged few. And this governance project has intervened at the most intimate, epistemic level; that is, through infiltrating and moulding cognitive processes, the very modes of thinking, as well as the intricate spectrum of social and cultural practices. ${ }^{11}$ In rereading/ deconstructing the colonial legacies as well as the gender and sexual hierarchies that constitute human rights, the scholarship has exposed how this project is incapable of meeting its promise of delivering freedom to 
the disenfranchised. This scholarship has provincialized the universal claims of international human rights law and problematized the extractive and appropriative aspects of its proclaimed progressive sensibilities, where colonial-era conditioning and policies continue to resonate in the postcolonial present, and to reproduce the injustices of multiple marginalization and exclusion. While there is a compendious literature available on the strengths and limitations of human rights advocacy, I address the normative and regulatory effects of this advocacy specifically in relation to gender and alterity, including sexual and cultural difference, and examine the limits of human rights in its self-appointed role as a salvific force that can bring about freedom in these domains. I pursue this inquiry through a series of chapters that demonstrate the ways in which the freedom of a particular disenfranchised subject - the sexual subaltern, the exploited/abused woman, the veiled woman - is envisioned and pursued within the human rights paradigm. Specifically, I examine the human rights strategies of progressive groups, in particular feminists, and women's rights and sexual rights advocates, in the international legal arena as well as within specific domestic contexts, including various liberal democratic countries, recognizing the interconnections between the international and domestic legal regimes. I provide an alternative reading of this advocacy to illuminate how these engagements constitute and inscribe the subject into specific ways of being free - ways that are aligned with a neoliberal, wealth-producing, heteronormative, reproductive framework, as well as with sexual, cultural, racial and religious prescriptions. The analysis places into question whether the bestowal of more rights has resulted in less violence against women, more justice for sexual subalterns or more equality for the cultural 'Other', all of which would presumably be part of the end goal of freedom pursued through human rights. My discussion is illustrative and intended to highlight how concepts of freedom and subject formation are contingent upon dominant gender, sexual, cultural and religious norms becoming normalized, naturalized and universalized within the liberal/neoliberal framings of the rights project. In this guise, human rights appear incapable of delivering on their promise of freedom.

While the discussion does not provide a comprehensive account of freedom - an amorphous concept that means different things to different people - the illustrative examples counsel in favour of pausing for deeper reflection on the pursuit of freedom in and through human rights advocacy, given its contradictory and at times exclusive and disempowering effects. The central problematic that I confront in this book, then, is that human rights are universal and necessary tools that we cannot not want, to paraphrase Gayatri Spivak writing in a different context, even 
though they cannot give us what we do want - that is, freedom. And if this is indeed the case, then what can give us what we want? Part of the answer to this question rests in being open to the trajectories of freedom delineated within alternative, non-liberal philosophical registers.

\section{METAPHORS OF FREEDOM}

I make my arguments by working with two metaphors. The first is the fishbowl, which represents the liberal constellation that shapes and disseminates mainstream human rights advocacy and scholarship, as well as particular understandings of freedom. There is no hegemonic definition of freedom within the rights schema but, when the latter malfunctions, reparative and restorative solutions are inevitably sought within the fishbowl and the liberal episteme that underpins its operations. Solutions for rights-related problems and crises are rarely envisioned beyond it. Freedom continues to be articulated through the fishbowl knowledge and certitudes that are structured, reinforced and repaired within a limited liberal framework. Enclosed within the fishbowl, human rights and the pursuit of freedom within the liberal paradigm are partly defined, and their terrain of operations calibrated, against a powerful mistrust and fear of non-liberal epistemological traditions with sources outside this confining ideological sphere. These traditions, and their different understandings of freedom, are invariably viewed from within the fishbowl as an aggressive-cum-regressive threat to its hegemonies.

However, as systematically delineated in the chapters of this book, contemporary human rights advocacy is being engulfed by a sense of despair and stasis as it becomes increasingly evident that the accumulation of further rights, as well as efforts at repair, restoration or rehabilitation of the project, have clearly not resulted in more freedom for the disenfranchised. The accumulating fears and anxieties that inform human rights advocacy today ultimately expose the illusoriness of the modalities of freedom envisioned - for liberals themselves, as well as for their non-liberal 'Others'. I explain this illusion through the use of a second metaphor: the rope/snake metaphor wherein the perceiver mistakes the object of perception, a rope, to be a snake and reacts/acts accordingly. This metaphor, drawn from the non-liberal episteme of Advaita (lit. 'not two') mentioned above - a philosophical tradition of non-duality from the subcontinent - suggests that freedom can only be experienced through the perceiver understanding the root error of her (mis-)perception; that is, the seeing of what is not, in what is. ${ }^{12}$ Such discernment, when consciously and repeatedly practised, corrects the 
perception and leads to correct external action and outcome. Quite specifically, in this episteme, the persistent, proliferating misjudgements that arise from the distorted logic of dualistic thinking resolve in the perceiver or observer.

In a Christian tradition, the snake is symbolic of evil, danger or a malevolent influence. Transposed into human rights terms, she represents the threat posed by the fear of an illiberal, unintelligible, regressive 'Other' to the very idea of human rights - and therefore, as undeserving of such rights, is to be coerced, incarcerated, subjugated or eliminated. However, the snake is read very differently within the non-liberal epistemology of non-dualism, where she is an illusion or appearance, produced by the perceiver. Fixating on the presence of this apparent snake, its particular features or its potential to harm brings the deluded observer no closer to discerning the truth - that the object perceived is actually the rope. The threat, the supposed 'snake', is not really there; the entity that actually does exist, the rope, becomes evident only through the perceiving subject. Through a constant practice of introspection/ correction that alters and expands awareness, the perceiver's responses to both 'snake' and 'rope' are fundamentally transformed. And freedom rests in this understanding.

The metaphorical framing of my argument in terms of the rope-snake finds resonance in the latter part of this book - Chapters 6 and 7 - when I address the importance of self-scrutiny and the turn inwards as a central feature of freedom, as enunciated within non-liberal alternative epistemologies that focus on the concept of non-dualism. In terms of my argument in this book, the (mis)perceived entity of the 'rope-snake' with its equivocations, contradictions and ambivalences - is, at one level, symbolic of the illusory rationale so cherished by its liberal adherents, proponents and actors: that human rights can actually, ethically and equitably procure and secure lasting freedom for all constituencies of the disenfranchised. Thus, while the rights apparatus may be viewed as a successful mode of emancipation for liberal advocacy, in real terms it may serve to further bind the disenfranchised through the overtly and covertly normative and regulatory functions of the project. The core illusion in the liberal rights paradigm rests specifically in two sets of exclusions that inform its universalist claims. First, the paradigm excludes those subjects who are constituted as either unassimilable or incommensurate, and thus fail to conform to the dominant normative arrangements that constitute part of the liberal scaffolding of freedom. Second, in monopolizing the space of freedom, this paradigm negates, suppresses or marginalizes alternative, non-liberal and, quite specifically, non-Western understandings of freedom. 
At another level, and more importantly, the snake-rope metaphor is a subjective process - it is applicable only in reference to interiority and self-reflection. The metaphor is a technique for the observer or thinker or perceiver to correct the error in her perception. In this respect, the metaphor is an epistemological crux, where freedom lies in the discernment of the error - that the rope is not a snake. This understanding is arrived at through neither external pursuit nor external search, but through an internal process of reflection, correction and understanding that frees the observer from her misunderstanding and misperception, and precludes her from undertaking an action on the basis of this misunderstanding and misperception.

Using these two metaphors, I argue that after the disillusionment with human rights we are not in the epistemic free fall that seems to so unsettle the rights establishment, activists and scholars. The urge to alleviate the current critical despair by giving human rights a makeover and to retrieve it as a hopeful project within a liberal universe is not necessarily the only option, nor even a viable one. I suggest that the turn back to human rights in search of this goal - not only by liberal scholars, but also at times by critical scholars - is not a productive one. ${ }^{13}$ This turn is actually reflective of the fear and anxiety underlying the refusal to explore alternative non-liberal registers and lifeworlds, not only because they are assumed to be illiberal and hence threatening, but also because of the entrenched hubris of the liberal conviction that the liberal project is the central means for securing freedom. Rather than succumb to paralysis and denial, we need to confront our despair - but, as I discuss in Chapter 5 , the approach should not be through a renewed faith or reinvestment in the human rights project (as proposed by several scholars), nor through a bottom-up paradigm which seeks to recapture the originary dissonant and revolutionary spirit assumed to be integral to human rights. Instead, we need an approach that enables a delinking of the rights schema itself from dominant liberal understandings of freedom, and to explore whether and how non-liberal understandings of freedom can productively address and alleviate the current disillusionment with human rights.

Contemporary critiques erode the claims of liberal freedom to either secure the happiness of the individual through advocacy of 'the good life' or to focus primarily on the alleviation of suffering through a minimalist trajectory, and they also raise some crucial questions. Does freedom, understood as either the promotion of happiness or the reduction of suffering, inevitably marginalize other possible specific methods of personal and political emancipation? What kinds of subjects and political cultures are produced and manipulated, affirmed or negated through these types of interventions? I posit that the real project of human rights today is 
not its assumed salvific, benevolent, altruistic, universalist substrate but its constitutive, regulatory, exclusionary agenda that continues to produce and privilege certain 'free' subjects/subjectivities over a multitude of unfree/ less free others. My argument in favour of a conscious shift towards exploring articulations of freedom beyond the fishbowl requires relinquishing the fear and anxiety that characterizes both critical and mainstream approaches to human rights, where non-liberal epistemological spaces are often equated with illiberalism, primitiveness, irrationality and threat. Such recognition involves taking seriously the reorientation and deconstruction of dominant thinking about human rights by critical scholars and acknowledging it as a governance project rather than a freedom project. It also involves taking this critique in a productive direction, which includes a willingness to turn towards and engage affirmatively with non-liberal epistemological spaces in the search for a genuinely meaningful articulation of freedom.

\section{TEXTUAL CONTENT AND STRUCTURE}

Several chapters in this book draw on lectures and keynotes that have been written and delivered at different points of time and for different occasions. These include invitations to speak about the complex relationship between human rights, justice and 'precarious desires'; to discuss the political possibilities of human rights in the context of the despair that has overtaken feminist and progressive politics; to analyse how women's rights advocacy on sexual violence at the domestic and international level may have reinforced the rise of a sexual security regime; to address the relationship between culture and freedom, and the coercive dimensions of human rights in relation to the Islamic practice of veiling; and to examine the understanding of freedom that is emerging in contemporary discourses on queer rights in both the postcolonial and international legal arenas. The adhesives that bind these interventions are all situated within a critical, quite specifically postcolonial feminist tradition, which does not assume that liberalism is the default position. Rather, this tradition has the ability to resist the northern gravitational pull of understanding and critiquing the world primarily through a liberal imaginary, as well as to accommodate in a productive way the inscriptions of freedom enunciated in various non-liberal philosophical traditions. At the same time, it does not subscribe to a nativist presentation of seemingly uncontaminated, indigenous epistemologies where, in fact, historically embedded caste and sexist and racist relations of power are 
also at work. Rather, the capacity to accommodate non-liberal philosophical possibilities may be the key to transforming the ways in which we imagine the world as well as catalyse more creative and meaningful imaginings of how to be free within it.

\section{Liberal Freedom and the Fishbowl}

As stated previously, the understanding of freedom that has informed human rights is fully framed within a liberal paradigm - what I designate as the fishbowl. And this paradigm includes a range of ways in which freedom is to be achieved, including through negative freedom, positive freedom, republican freedom and freedom in terms of the capabilities approach. In all these articulations, the individual is regarded as the central unit of the social sphere. Within the ambit of human rights, the key concern is how to maximize individual freedom through rights accumulation as well as how to hold states accountable for the withholding, suppression or violation of basic human rights. Battles are waged to secure rights set out in the main UN human rights documents in the conviction that more rights will lead to more freedom and happiness. In Chapter 1, 'Liberal Freedom in a Fishbowl', I argue that the central features of liberal freedom - as a progressive, external end goal, and as linked to liberal individualism - have been exposed by critical legal thinkers as obscuring the normative assumptions and political agendas that are reinforced or advanced in and through the discourse of rights. Such critiques have revealed how freedom is linked in the contemporary moment not only to an increasingly narrow understanding based on an economic formulation realized through a neoliberal market enterprise, but also to a distinct understanding of the subject as an unveiled, sexualized consumer. The critiques reveal how liberal freedom, valorized as the pinnacle of progressive thought and civilizational virtues, is explicitly and implicitly informed by political projects emanating from the fishbowl.

I analyse three key claims of liberal freedom in relation to human rights. The first is the claim that human rights are not linked to freedom, and that their only role is to reduce cruelty and suffering - they should, in this view, do nothing more in relation to the disenfranchised subject. The second is the belief that culture, antiquity and tradition have been obstacles to human flourishing, and that those oppressed and hindered through these modalities can be rescued through the universalist premise of human rights and liberal individualism. The third is the notion that human rights are based on the existence of a common universal subject. The analysis establishes my assertion that the current framework of 
human rights - which has its source in the liberal enunciation of freedom - is materially and ideologically grafted onto a governance project; this assertion informs the subsequent discussion in this book regarding the implications of such vascular fusion for human rights advocacy in relation to gender and alterity. The argument is not that the human rights terrain should be abandoned, but rather that it should be engaged precisely because it is an arena of power, even while there is a simultaneous need for rights to be actively dissociated from the assumption that they can deliver the disenfranchised into lasting freedom. Given the failure of the liberal-based rights schema, the rationales for such freedom must be sought through alternative non-liberal philosophical registers.

\section{Evaluating LGBT and Feminist Human Rights Advocacy}

In Chapter 2, 'Precarious Desires and the Pursuit of Rights', I discuss the anatomy of freedom and how certain subjects come to be recognized in human rights discourse as experiencing injuries and harms that are deemed as unjust, reparable or remediable, in a context where freedom is directly equated with securing rights that will render these marginalized groups more assimilated, that is, more mainstream. This chapter analyses how rights interventions occur within and against already established normative and material frameworks, namely, conventional racial, cultural, sexual and civilizational arrangements that inform both the ideology and the apparatus of human rights. The chapter specifically examines how pursuits of human rights have an impact on 'precarious desires', with a focus on LGBT advocacy. Further, it considers how such pursuits, while conferring recognition and legibility, not only reproduce the normative framework in which precarity and precarious identities are addressed, but also clearly incorporate the entitled subject, the rights-seeking subject and the illegible non-subject within a space where freedom is strongly defined in terms of the market and consumer agency. ${ }^{14}$ I elaborate on how rights interventions simultaneously transform the disempowered 'unhappy queer' into a 'happy queer subject', ${ }^{15}$ one whose experience of freedom is directly affiliated with the neoliberal rationality articulated by Foucault - specifically, the political/economic schema that finds its central manifestation in the logic of the market.

In Chapter 3, 'Freedom, Women's Rights and the Rise of the Sexual Security Regime', I illustrate how women's rights advocacy is moving further and further away from its promised goal of freedom in the context of human rights. As my starting point, I take the responses to the sexual assaults committed on women in Cologne on New Year's Eve in 2015, as 
well as those to the gang rape, and subsequent death in hospital from related injuries, of a young woman in Delhi on 16 December 2012 - an atrocity that catalyzed nationwide protests and received global attention. The chapter traces how these appalling episodes of violence against women invited activist and state responses that strengthened the security and sexual surveillance apparatus governing gender more generally and Third World women quite specifically, and witnessed an increased alignment with the state of progressive forces, including feminists. The consequent increase in overt and subtle control asserted over women's choices raises questions as to how and why decades of women's human rights advocacy have produced outcomes that have actually moved in the direction of unfreedom rather than freedom.

While rights discourse has indeed provided a platform for women to narrate and challenge abuses and harms that have been hidden from activist scrutiny, this evidentiary mode should not be equated with freedom. I illustrate how gender rights advocacy has been thoroughly implicated in maintaining gender binaries and promoting a carceral vision by discussing interventions in the context of anti-trafficking, as well as the Security Council Resolutions 1325 and 1820 on gender, peace and security in conflict situations. These interventions have invariably translated into a general tightening of the sexual security regime in accordance with national and cultural imperatives. Further, they have been displaced into a First/Third World divide, thus enabling a broader justification for the establishment of security regimes and the unleashing of military and 'civilizing' missions in developing countries in the name of women's rights. The work of protecting local women and procuring their freedom from various cadres of native oppressors, in what are regarded as illiberal contexts - dominated by hostile, unintelligible, irrational, misogynistic 'Others' - is, in fact, achieved through liberal forces imposing their own righteous counter-rhetoric and aggressive protocols of unfreedom in those regions.

The conflation of diverse issues within women's human rights advocacy with an almost exclusive focus on violence against women and related criminal justice measures, and directed partly by what Janet Halley has described as 'governance feminism', has moved decidedly away from the idea of human rights as a freedom project. ${ }^{16}$ Women's human rights advocacy has instead come to operate as a tool for disciplining and intensifying the surveillance of women's sexual conduct and strengthening the security apparatus of the state. It remains no coincidence that this approach converges with the robust contemporary script of neoliberal governmentality and the increasing 'economization' of political life that I discuss in Chapter 2. 
Chapter 4, 'Alterity, Gender Equality and the Veil', addresses the issue of gender in relation to equality and alterity, specifically in the context of the human rights controversies surrounding Muslim women's rights and the scripturally sanctioned, popular practice of veiling. Drawing upon the analytical insights of postcolonial feminism, this chapter demonstrates how the anatomy of the right to gender equality is shaped by dominant sexual, gender and cultural norms that set out fundamentally nonnegotiable unfree terms for social inclusion and full citizenship. Focusing largely on the controversial French laws banning various manifestations of the veil, as well as on decisions of the European Court of Human Rights upholding the validity of such bans, I demonstrate how universality, which is claimed within the liberal constellation as the basis for freedom in human rights, is in fact a modality that is highly particular, exclusionary, differential and deeply conditioned by cultural and gender norms.

The argument illustrates how states deploy the logic of gender equality as a racist technique to profile and target French Muslims, render their religious and national identity suspect and deny them their rights. The veil bans are trumpeted in the name of advancing women's right to gender equality, but this process also ensures that a very specific understanding and desirable image of the gendered subject (essentialized, unveiled and sexualized) is presented as worthy of reinforcement and protection within the human rights regime. This understanding discounts the fact that liberal conceptions of freedom informing such interventions are based on the patronizing and paternalistic conceit that the West knows what is best for the inferior/oppressed 'Other'. And as Saba Mahmood has so eloquently and persuasively argued, opponents of veiling also completely ignore the intimate and affective dimensions of this practice; in particular, how articulations of the experience of freedom through the veil, rather than through freedom from the veil, can emancipate women for whom the veil functions simultaneously as a significant spiritual/cultural/ethical choice and as a way of life. ${ }^{17}$

Human rights as an advocacy tool, while prompted by radical movements and visions, are ultimately drawn into compliance with a specific normative order that is both de-radicalizing as well as regulatory and discriminatory. I do not take the position of scholars who consider the human rights project as a failed one that needs to be replaced, ${ }^{18}$ or as a project that has repudiated its initial 'moral clarity' - a repudiation based on Eurocentric roots that have coerced rights advocacy into becoming an ally for the humanitarian and military interventions of powerful liberal states against various configurations of backward and violent 'Others'. I recognize not only that human rights are implicated in power and have 
powerful effects, but also that they constitute a terrain acquired arduously and at great cost - a terrain that cannot and should not be surrendered. As emphasized earlier in this Introduction, human rights are something 'we cannot not want', despite the injustice of preferential bestowal and the relentless reification of the liberal paradigm, wherein rights are embedded as the universal and desirable norm.

History continues to prove that the normative content of human rights can be altered and disrupted by those who have never been recognized as human by the entitled majority, or whose humanity has been positioned at the lower end of the civilizational hierarchy within the liberal (imperial) project. While these disruptive possibilities have concretely opened up some spaces of increased legibility and protection for racial and religious minorities, colonial subjects, queers and women, all of whom have sought to be recognized within the human rights apparatus, these 'victories' do not equate with the idea that rights have actually ensured more permanent freedom for these constituencies. The early chapters of this book illustrate that engagement with human rights, while at times urgent and compelling, has demonstrated little capacity to actualize the desire for lasting freedom, and that human rights are not simply pragmatic instruments for the pursuit of a minimalist agenda to alleviate suffering and ensure bare survival that puts the disenfranchised subject in a position to make more choices. The outcomes of the human rights interventions discussed in these early chapters provide little scope for understanding freedom outside of liberal conceptions generally, or the current phase of economic global expansion more specifically, where human life is subordinated to the neoliberal market and includes the commodification of suffering. ${ }^{19}$ More significantly for the purposes of my book, the notion that divergent understandings of freedom have always existed outside of the liberal and neoliberal imaginaries and related market terms is either barely considered by those who shape, support and implement the rights regime, or considered inherently alien and therefore irrelevant to the recursive ideological currents within the fishbowl.

Chapter 4 sets the stage for the argument put forward in the final three chapters of the book, where it is proposed that the concept of freedom should be actively delinked from the human rights project as formulated and imposed by the liberal imaginary, and should instead be explored within affective as well as alternative philosophical registers. The stark realization that human rights do not equally deliver to all constituencies prompts us to ask: what do we do when the emancipatory hope incorporated into the liberal imaginary fades? Where do we turn when our critiques abandon us on the final precipice of the liberal vision - our 
backs to roiling violence, our thoughts overwhelmed by a sense of approaching apocalypse, even as we stare down into what seems like an epistemic abyss? Do we refashion the tools that have constituted the arsenal of liberal reform, and stage a hopeful reinvestment in the human rights project in anticipation that such reinvestment might draw aside the curtain of pessimism and allow in some streams of light? Do we continue to cling to our critical relationship with the human rights movement and the liberal concepts that have, with naive idealism and revolutionary fervour, held out hope for a different and better future? Or do we resign ourselves to embracing the myth of human rights as a minimalist endeavour or available firefighting technique that may alleviate some forms of human suffering, and do 'nothing more', despite knowing that they are always actively pushing, protecting and reinforcing other agendas? These and similar concerns are informed by an underlying fear on the part of human rights advocates and critical scholars that there are no other options, or only illiberal alternatives, available as solutions to the current crisis. In the later chapters of this book, I argue that these fears constitute obstacles to the work of shaping and implementing modalities of emancipation, and are based on an uninterrogated commitment to viewing liberalism as the default position or source of all emancipatory knowledge or as undisputedly the superior political philosophy.

\section{Freedom beyond the Liberal Imaginary}

What remains intriguing in the state of epistemic crisis is how the despair generated by the devastating critiques of human rights as instruments for the differential distribution of justice, or as facilitating a carceral politics, or as contradictory, or as a governance project that disciplines, regulates or constitutes subjects rather than emancipating them does not appear to have shaken the commitment to human rights as a moral and social good, or the continuing, unrelenting faith in its universal application. The terrain of rights is continually enhanced, reiterated and reinforced through its function as a site of continuous engagement by disenfranchised and marginalized groups, as well as by scholars who have recognized the limitations of human rights but found ways to reinvest in this project through re-theorizing its trajectories and thus nourishing the template of its futurity. The powerful critique of human rights has not undermined the foundations of the project or its power as a human ideal in the least. So we are compelled to ask: what is the allure of human rights, even when its promise of freedom that includes a specific vision of happiness or a better life remains unrealized, or elusive, or illusory for a large proportion of humanity? Does the terror and despair generated by 
the prospect of rejecting human rights, or by the conclusion that they have no redemptive or reparative value, galvanize the urge to pull it back from the brink and produce hopeful counter-narratives to these dystopian scenarios? Is there a limit to the capacity to envision human rights as the best route to political and personal freedom that can be hoped for in these dark times?

I argue that we need to take our sense of despair in a different direction. The human rights project has reached an impasse, and finds itself inhabiting a moment of stasis that also affords an opportunity for a more diligent and thoughtful consideration of the meaning of freedom in another set of registers - in particular, outside of the liberal imaginary and the structures of liberal legality that also construct the deserving, desirable, entitled, sovereign subject. I argue in favour of the politics of reflectivity and discernment, which can be utilized as a vital resource, method and modality in the current phase of global violence, chaos and upheaval. The tense equation of a liberal rights critique with pessimism, and a liberal rights deployment with optimism, has deferred a pending ideological implosion within the fishbowl, but has not defused it. This obdurate interlocking of scholarly and activist energies takes us not into clarity, but into further stagnation and confusion.

Chapter 4 marks the moment when my argument sloughs its skin through a controlled, purposive and complete peeling back. In the final three chapters of the book, I consciously stage a turn away from our conditioned view of human rights as a mechanism for freedom, towards possibilities for lasting freedom nestled in a turn to the intimate as well as alternative non-liberal registers where freedom rests in self-inquiry and the transformation of the self. In ideational terms, any fresh insight into the concept of freedom - one that would equally apply to and help all constituencies - mandates a calibrated loosening and inversion of the liberal sheath; a systematic, concentrated, diligent act of new cognition/ re-cognition. This critical distancing from the familiar episteme and its hegemonies turns inside out the core framings of the human rights project - the rational subject, linear time and liberal freedom.

Chapter 5, 'Despair, Redemption and the Turn Away from Human Rights', elaborates on the enormous reluctance to let go of human rights as a redemptive moral pursuit, despite the knowledge that rights in their contemporary incarnation cannot deliver on their promise of freedom for women and cultural and sexual subalterns. I examine some of the efforts to reclaim the human rights project through renewal, recuperation and reinvestment, which all persistently adhere to the liberal vision of human rights as a proved mechanism for freedom. Though some of these efforts pursue the Foucauldian position on rights as regulatory and disciplinary 
techniques of governance, they resubmit to the coercive logic of the liberal universe as the sole location within which all solutions for human suffering and diagnostics of freedom must be found. This turn back to a schema of restoration via rights fails to explore the dynamic potential and generative capacities of experiential conditions of despair, hopelessness and failure. The second part of Chapter 5 draws on feminist and queer affect theory to explore the turn to the intimate. I discuss how this turn is inherently a valid source of self-affirmation and freedom. A continued yearning for or attachment to human rights may not be in the subject's best interest, and indeed may be a form of 'cruel optimism' that becomes an obstacle to human flourishing. ${ }^{20}$ The existent human rights project requires compliance with the normative architecture of freedom and happiness instituted by liberal/neoliberal paradigms; those who do not comply become failed subjects. ${ }^{21}$ Yet not only does this very site of negativity and failure draw attention to the granular aspects of daily suffering and the existential strategies that enable hope and survival within even the most hopeless, unliveable situations, but the foregrounding of affect and the intimate also opens up possibilities for examining freedom in alternative registers. It mandates a turn away from the doctrinaire liberal position that human rights are fundamentally a freedom project. It also inscribes the refusal of failed subjects to submit to a regulatory regime that compels conformity with the scaffolding of dominant sexual, gender and cultural norms which, in the liberal imaginary, constitute the enfranchised, empowered subject and the ideal of freedom.

Chapter 6, 'Seeking Freedom through Alternative Registers', explores the possibility of relocating the discursively constituted subject of human rights advocacy within a non-liberal philosophical tradition that may open up space for alternative understandings of, and realizing, the desire for lasting freedom through a crucial focus on the self and self-inquiry, and the adoption of a reflective rather than reflexive politics. The argument pushes back against the embedded notion that all political hope and possibility rests within a liberal philosophical tradition which can be actualized partly through the pursuit of human rights. To illustrate what I mean by the 'turn towards' understanding freedom in alternative registers, I examine the intellectual shift that manifested in the work of two critical theorists: Eve Sedgwick and Michel Foucault. I discuss Sedgwick's attraction to Buddhism and her engagement with Mahayana epistemology, which enabled her to theorize positive 'affect' and describe how the capacious and liberating idea of cyclic time, together with the interdependent, impermanent, experiential 'non-self' within this tradition, contrasts sharply with the limitations of liberal individualism and linear 
chronologies on which human rights are based. I also discuss Foucault's concept of 'political spirituality' in the context of his interest in the Iranian revolution, and the influence of canonical Shi' ism upon his thought. I describe how his theorizing of the notion of revolution beyond a liberal paradigm quite specifically involved a reconfiguration/ reinscription of the discursively constituted self and its finite potentialities.

I end the chapter with a discussion on how any such intellectual and emotional turn away from the liberal paradigm can be perceived as threatening and invite hostility and even, at times, violence. I conclude with a close reading of Iranian-born artist Shirin Neshat's video installation Overruled (2012), an allegorical work referencing Persian Sufism and based on a historic criminal trial that is ostensibly about a challenge to state-sanctioned freedom of expression, but is in fact about the expression of freedom in an alternative register. The work offers a complex appraisal of the embedded suspicions and phobias underlying the majoritarian resistance to individual and collective unfamiliarity or difference, including the turn, by those designated as failed subjects, away from a liberal episteme to embrace an alternative articulation of freedom. It also scrutinizes the reluctance to turn away from the assured taxonomies of sanctioned systems of thought and reorient towards alternative spaces of engagement and the narratives produced therein.

Chapter 7, 'Freedom from the Fishbowl', elaborates on the implications of a radical turn away from human rights and its normative prescriptions. I examine how re-conceptualizations of the subject, time and freedom within the epistemology of the specific subcontinental philosophical tradition of non-dualism (Advaita) offer possibilities for realizing the desire for meaningful freedom and happiness. I consider how engagement with this tradition is relevant for human rights advocacy, and how it opens up space for women and sexual subalterns to intervene on their own behalf and pursue strategies of freedom outside of a valorized liberal imaginary. Such a shift in perspective requires a willingness to detach from theoretical projects that have held out so much political hope and possibility, without fearing that nihilism will be the inevitable outcome. This turn away from the fishbowl is not a culturally exotic move. Rather, it reflects a serious concern with the question of how we can continue to pursue the idea of freedom and its connections to happiness and the 'good life', in the aftermath of the dismayed and immobilized contemporary critique of human rights.

In the epilogue, I bring together the analysis presented in the book and reread some historical and contemporary struggles, cases and texts 
involving alternative expressions of subjectivity against which our conventional concepts of freedom can be measured. These articulations illustrate the counter-hegemonic potential that resides in non-liberal epistemologies that are available, although not exclusively, in postcolonial spaces. They present alternative registers of being and becoming in the world, thus refuting the universalist assumption that freedom must already, and always, be schematized and instituted by a liberal imaginary. Without falling into the trap of convenient cultural relativism, the epilogue's narratives invoke the potential for human rights to be aligned with, though not necessarily commensurable with, a non-liberal paradigm of freedom.

This book avers that freedom is unlikely to be found in the insistent protocols of rights accumulation that serve to further embed the seeking subject within the terms of a liberal imaginary and, in the contemporary moment, impale the subject within a mode of uncompromising economic imperialism based on neoliberal rationality. The arguments presented in this book seek to displace liberal framings and international human rights understandings of freedom, even while rights remain important tools for conducting a conversation with the official state apparatus. The displacement operates at two levels: I thematically disorient and question the liberal human rights project through the 'fishbowl' and 'rope-snake' metaphors; and I provincialize and vernacularize the rights project by including non-Western, non-liberal epistemologies as valid and valuable strands of inquiry. My project is an audacious and radical one - in essence, it seeks to theoretically disrupt the axiomatic and hegemonic liberal positioning of human rights as the irrefutable core ideology for delivering the many constituencies of the disenfranchised into lasting freedom. Thus, the main contribution of this book is to identify new, revolutionary ways of pursuing freedom, highlighting the central features of non-liberal philosophical epistemologies and traditions that involve a turn inwards and necessarily require the self-transformation of the subject.

I end here by re-invoking the snake metaphor. What the passer-by erroneously observes as a snake forces her to instinctively move away or take another route to escape its menacing potential. However, if instead of deviating she engages in a closer investigation of both the external phenomenon and her internal responses to it, she may come to realize that the 'snake' is something else entirely: a rope, an object that in appearance resembles what she fears, but in actuality holds no threat. The real danger, in fact, is a profound error in perception that compels the observer to mentally superimpose what is not upon what is - an action that embeds her in confusion and may trigger an unsettling cascade of 
internal and/or external reactions. Transposing this logic of observation/ self-observation onto the human rights schema, we might say, in the simplest terms, that rights advocacy intervention thus requires careful discernment and thoughtfulness. At a deep philosophical level, the rope/snake metaphor is about the subject and her discernment, which involves a simultaneous and meticulous scrutiny of the perceiving subject as well as of the perceived object, and through which fundamental errors in one's perception - of oneself and of one's 'other/s' - can be corrected. Discernment collapses the conventional categories of 'being' and 'doing', the distinction between the subject who 'is' and the subject who 'does'. And only through such discernment can the potential for further inscribing the wheel-ruts of error be appropriately curtailed, and the futile, recursive and endless ideological circumambulations within the fishbowl be effectively terminated.

\section{NOTES}

1. Ben Golder, 'Beyond Redemption? Problematising the Critique of Human Rights in Contemporary International Legal Thought', London Review of International Law 2, no. 1 (2014): 79. See also Ben Golder, Foucault and the Politics of Rights (Stanford, CA: Stanford University Press, 2015).

2. Wendy Brown, Politics Out of History (Princeton, NJ: Princeton University Press, 2001), pp. 5-6.

3. Costas Douzinas, The End of Human Rights: Critical Legal Thought at the Turn of the Century (Oxford: Hart Publishing, 2000), p. 2.

4. See, among others, Antony Anghie, 'International Human Rights Law and a Developing World Perspective', in Routledge Handbook of International Human Rights Law, eds. Scott Sheeran and Nigel Rodley (London: Routledge, 2013), pp. 109-25; Antony Anghie, Imperialism, Sovereignty, and the Making of International Law (Cambridge: Cambridge University Press, 2007); José-Manuel Barreto, Human Rights from a Third World Perspective: Critique, History and International Law (Newcastle upon Tyne: Cambridge Scholars Publishing, 2013); Dianne Otto, ed., Gender Issues and Human Rights, 3 vols (Cheltenham: Edward Elgar Publishing, 2013); Upendra Baxi, The Future of Human Rights, 3rd ed. (New Delhi: Oxford University Press, 2008); Doris Buss and Ambreena Manji, 'Introduction', in International Law: Modern Feminist Approaches, eds. Doris Buss and Ambreena Manji (Oxford: Hart, 2005), pp. 1-16; Subrata Sankar Bagchi and Arnab Das, eds., Human Rights and the Third World: Issues and Discourses (Lanham, MD: Lexington Books, 2012); David Kennedy, The Dark Sides of Virtue: Reassessing International Humanitarianism (Princeton, NJ: Princeton University Press, 2004); Makau Mutua, 'What is TWAIL?' ASIL Proceedings [2000]; Makau Mutua, Human Rights Standards: Hegemony, Law, and Politics (Albany, NY: State University of New York Press, 2016).

5. See, for example, Douzinas, End of Human Rights, p. 1.

6. For a further discussion on the 'dark side' or destructive consequences of the human rights project see Emma Larking, 'Human Rights Rituals: Masking Neoliberalism and Inequality, and Marginalizing Alternative World Views', Canadian Journal of Law and Society/Revue Canadienne Droit et Société 32, no. 1 (2017): 1-18; Kathryn McNeilly, 'After the Critique of Rights: For a Radical Democratic Theory and Practice of Human Rights', Law and Critique 27, no. 3 (2016): 269-88; Diana Tietjens Meyers, 'Recovering the Human in Human Rights', Law, Culture and the Humanities 12, no. 3 (2016): 474-84. 
7. Ranajit Guha and Partha Chatterjee, The Small Voice of History: Collected Essays (Ranikhet: Permanent Black, 2010). See also Ranajit Guha, 'On Some Aspects of the Historiography of Colonial India', in Subaltern Studies: Writings on South Asian History and Society, ed. Ranajit Guha (Delhi: Oxford University Press, 1982), pp. 1-8. For recent postcolonial critiques of dominant narratives and hegemonic discourse see Fabian Klose, 'Human Rights For and Against Empire: Legal and Public Discourses in the Age of Decolonisation', Journal of the History of International Law 18, nos. 2-3 (2016): 317-38; Sebastian Bonnet, 'Overcoming Eurocentrism in Human Rights: Postcolonial Critiques Islamic Answers?' Muslim World Journal of Human Rights 12, no. 1 (2015): 1-24.

8. See, for example, Samuel Moyn, The Last Utopia: Human Rights in History (Cambridge, MA: Harvard University Press, 2010). Moyn argues that human rights are contemporary in origin and emerged as globally relevant in the 1970s after the failure of revolutionary Communism and nationalism. A contrasting view is presented by Martinez, who traces the emergence of human rights law against the struggle to end the slave trade. See also Samuel Moyn, Human Rights and the Uses of History (London: Verso, 2014); Jenny S. Martinez, The Slave Trade and the Origins of International Human Rights Law (Oxford: Oxford University Press, 2012); Lynn Hunt, Inventing Human Rights: A History (New York: W.W. Norton, 2007); Christopher McCrudden, 'Human Rights Histories', Oxford Journal of Legal Studies 35, no. 1 (2015): 179-212.

9. See, for example, Stephen Hopegood, The Endtimes of Human Rights (Ithaca, NY: Cornell University Press, 2013); Eric A. Posner, The Twilight of Human Rights Law (New York: Oxford University Press, 2014).

10. Pheng Cheah, Inhuman Conditions: On Cosmopolitanism and Human Rights (Cambridge, MA: Harvard University Press, 2006). See also Anna Selmeczi, 'Who Is the Subject of Neoliberal Rights? Governmentality, Subjectification and the Letter of the Law', Third World Quarterly 36, no. 6 (2015): 1076-91. See further Nick Stevenson, Human Rights and the Reinvention of Freedom (Abingdon: Routledge, 2017).

11. Franz Fanon, Black Skin, White Masks, trans. Charles Lam Markmann (New York: Grove Press, 1967); Ashis Nandy, The Intimate Enemy: Loss and Recovery of Self under Colonialism (Delhi: Oxford University Press, 1983), p. 3; Albert Memmi, The Colonizer and the Colonized (New York: Orion Press, 1963); Walter D. Mignolo, The Darker Side of the Renaissance: Literacy, Territoriality, and Colonization, 2nd ed. (Ann Arbor, MI: University of Michigan Press, 2003); Edward Said, Orientalism (London: Penguin Books, 1978); Gayatri Chakravorty Spivak, 'Can the Subaltern Speak?' in The Post-Colonial Studies Reader, eds. Bill Ashcroft, Gareth Griffiths and Helen Tiffin (London: Routledge, 1995), pp. 24-8. For recent critical engagement with these texts, see Sarah Bracke, 'Is the Subaltern Resilient? Notes on Agency and Neoliberal Subjects', Cultural Studies 30, no. 5 (2016): 839-55; Bibhash Choudhury, Reading Postcolonial Theory: Key Texts in Context (Florence: Taylor and Francis, 2016).

12. The snake/rope metaphor is drawn from the expositions of the eighth-century philosopher Adi Śankara, whose work is discussed in Chapter 7. See more generally Śankarācārya, Śankara on the Absolute, trans. A.J. Alston (London: Shanti Sadan, 2004).

13. See Golder, 'Beyond Redemption?' Golder discusses the redemptive aspects of the work of three critical legal scholars in international and human rights law: David Kennedy, Anne Orford and Makau Matua. See also my critique of the positions of three critical/ postcolonial/feminist scholars - Costas Douzinas, Boaventura De Sousa Santos and Wendy Brown - and their recursive turn back towards human rights/liberal freedom in Chapter 5. For one response to Golder's arguments on the redemptive turn by critical scholars, see Geoff Dancy and Christopher J. Fariss, 'Rescuing Human Rights Law from International Legalism and Its Critics', Human Rights Quarterly 39, no. 1 (2017): 1-36.

14. See Wendy Brown, Undoing the Demos: Neoliberalism's Stealth Revolution (New York: Zone Books, 2015); Wendy Brown, 'Sacrificial Citizenship: Neoliberalism, Human Capital, and Austerity Politics', Constellations 23, no. 1 (2016): 3-14. See Foucault's lectures on neoliberalism as the new regime of governmentality in which 'homo economicus' is a particular mode of subjection and freedom is understood primarily in terms of freedom of 
the market: Michel Foucault, The Birth of Biopolitics: Lectures at the Collège de France, 1978-79, ed. Michel Senellart, trans. Graham Burchell (Basingstoke: Palgrave Macmillan, 2008).

15. Sara Ahmed, The Promise of Happiness (Durham, NC: Duke University Press, 2010), pp. $88-120$.

16. Janet Halley, 'Introduction to Governance Feminism,' in Governance Feminism: An Introduction, eds. Janet Halley, Prabha Kotiswaran, Rachel Rebouché, and Hila Shamir (Minneapolis: University of Minneapolis Press, 2018), pp. ix-xxii; Janet Halley, Split Decisions: How and Why to Take a Break from Feminism (Princeton, NJ: Princeton University Press, 2006), pp. 4-5; see also pp. 20-2.

17. Saba Mahmood, The Politics of Piety: The Islamic Revival and the Feminist Subject (Princeton: Princeton University Press, 2005)

18. Hopegood, Endtimes of Human Rights. Hopegood excoriates what he describes as the 'human rights industry' as a tool of conservative nationalists, religious forces and American power, arguing that the deployment of human rights serves the interests of international elites and assuages the guilt of the middle classes. See also Posner, Twilight of Human Rights. Posner argues that human rights are a failed project, incapable of functioning effectively to realize freedom due to their inherent ambiguities, sponginess and lack of consensus. He proposes that they be replaced by an economic framework based on a foreign aid model that has concrete and measurable indicators for poverty reduction.

19. Upendra Baxi, 'Voices of Suffering and the Future of Human Rights', Transnational Law and Contemporary Problems 8, no. 2 (1998): 159-60; Naomi Klein, The Shock Doctrine: The Rise of Disaster Capitalism (London: Allen Lane, 2007); Susan Marks, 'Four Human Rights Myths', London School of Economics and Political Science, LSE Law, Society and Economy Working Papers 10/2012 (2012), http://www.lse.ac.uk/collections/law/wps/ WPS2012-10_Marks.pdf; Elaine M. Lazaro, 'Thinking with Irigaray: On Asian Women as Objects of Conquest and Exchange', Kritike 11, no. 1 (2017): 94-107.

20. Lauren Berlant, Cruel Optimism (Durham, NC: Duke University Press, 2011).

21. Ahmed, Promise of Happiness, 150; Judith Halberstam, The Queer Art of Failure (Durham, NC: Duke University Press, 2011). For a critical engagement with Ahmed and Halberstam, see Mari Ruti, The Ethics of Opting Out: Queer Theory's Defiant Subjects (New York: Columbia University Press, 2017). 